УДК 322.122

Стащук Олена, докторка економічних наук, професорка, Волинський національний університет імені Лесі Українки, завідувачка кафедри фінансів м. Луцьк; ORCID ID 0000-0003-2622-7353 e-mail: staschuk.olena@vnu.edu.ua

Жук Марія, аспірант, Волинський національний університет імені Лесі Українки, кафедра фінансів, м. Луцьк, ORCID ID 0000-0003-3398-4416, e-mail: staschuk.olena@vnu.edu.ua

https://doi.org/10.29038/2786-4618-2021-03-54-60

\title{
ФІНАНСОВА БЕЗПЕКА ТЕРИТОРІАЛЬНИХ ГРОМАД, ЯК КЛЮЧОВИЙ ФАКТОР ЗАБЕЗПЕЧЕННЯ ЇХ СТАЛОГО РОЗВИТКУ
}

Особливості функціонування об’єднаних територіальних громад, котрі створені в процесі бюджетної та адміністративної децентралізації в Україні, передбачають формування специфічного механізму залучення та використання коштів, котрі спрямовуються на забезпечення сталого розвитку цих ОТГ. Тому дослідження особливостей забезпечення фінансової безпеки фінансових потоків територіальних громад набуває особливої актуальності в аспекті необхідності забезпечення їх сталого розвитку.

У статті розглядається специфіка фінансової децентралізації та особливості формування бюджетів ОТГ в сучасних умовах. Розглянуто принципи державно-приватного партнерства, як потенційного джерела інвестицій в розвиток територіальних громад.

Визначено, що забезпечення фінансової безпеки ОТГ базується на дотриманні фінансової дисципліни виконавчими органами громад, а також на основі ретельного планування і контролю надходжень та видатків до бюджету ОТГ. При цьому досліджено, що найбільш важливим елементом фінансової безпеки територіальних громад $\epsilon$ саме бюджетна, оскільки вона потенційно здатна забезпечити найбільшу частку фінансових надходжень на потреби сталого розвитку громади. Відповідно, визначено, що сучасна стратегія фінансової безпеки територіальних громад повинна базуватися на забезпеченні їх бюджетної безпеки.

Ключові слова: ОТГ, фінансова безпека, інвестиції, бюджетна децентралізація, фінанси територіальних громад.

Стащук Елена,

доктор экономических наук, профессор, Волынский национальный университет имени Леси Украинки, заведующая кафедрой финансов, г. Луцк

Жук Мария, аспирант, Волынский национальный университет имени Леси Украинки, Кафедра финансов, м. Луцк,

\section{ФИНАНСОВАЯ БЕЗОПАСНОСТЬ ТЕРРИТОРИАЛЬНЫ ОБЩИН, КАК КЛЮЧЕВОЙ ФАКТОР ОБЕСПЕЧЕНИЯ ИХ УСТОЙЧИВОГО РАЗВИТИЯ}

Особенности функционирования объединенных территориальных общин, которые созданы в процессе бюджетной и административной децентрализации в Украине, предусматривают формирование специфического механизма привлечения и использования средств, которые направляются на обеспечение устойчивого развития этих ОТО. Поэтому исследование особенностей обеспечения финансовой безопасности 
финансовых потоков территориальных общин приобретает особую актуальность в аспекте необходимости обеспечения их устойчивого развития.

В статье рассматривается специфика финансовой децентрализации и особенности формирования бюджетов ОТО в современных условиях. Рассмотрены принципы государственно-частного партнерства, как потенциального источника инвестиций в развитие территориальных общин.

Определено, что обеспечение финансовой безопасности ОТО базируется на соблюдении финансовой дисциплины исполнительными органами обществ, а также на основе тщательного планирования и контроля доходов и расходов в бюджет ОТО. При этом исследовано, что наиболее важным элементом финансовой безопасности территориальных общин является именно бюджетная, поскольку она потенциально способна обеспечить наибольшую долю финансовых поступлений на нужды устойчивого развития общества. Соответственно, определено, что современная стратегия финансовой безопасности территориальных общин должна базироваться на обеспечении их бюджетной безопасности.

Ключевые слова: ОТО, финансовая безопасность, инвестиции, бюджетная децентрализация, финансы территориальных общин.

\section{Olena Stashchuk, Doctor of economics, Professor, Lesya Ukrainka Volyn, National University, Department of Finance, Lutsk \\ Zhuk Maria, Postgraduate student, Lesya Ukrainka Volyn National University, Department of Finance, Lutsk,}

\section{FINANCIAL SECURITY OF TERRITORIAL COMMUNITIES AS A MAIN FACTOR FOR ENSURING THEIR SUSTAINABLE DEVELOPMENT}

The peculiarities of the functioning of the united territorial communities, which were created in the process of budgetary and administrative decentralization in Ukraine, provide for the formation of a specific mechanism for attracting and using funds aimed at ensuring the sustainable development of these UTC. Therefore, the study of the features of financial security of financial flows of territorial communities becomes especially relevant in terms of the need to ensure their sustainable development. At the same time, one of the main criteria of financial security is that it should include a number of structural elements related to ensuring the tax content of local budgets, and should ensure the differentiation of sources of funds by expanding funding from private investors, which provides for private-public scheme. partnership.

The article considers the specifics of financial decentralization and features of UTC budget formation in modern conditions. The principles of public-private partnership as a potential source of investment in the development of local communities are considered. Accordingly, it is the provision of proper cooperation with investors that allows local communities to increase the amount of funds that can be raised for projects related to their socio-economic development. Thus, the need to ensure transparent financial control over the receipt and use of these funds is a priority need of UTC in terms of ensuring their financial security. At the same time, although similar requirements apply to sources coming to the budgets of territorial communities, their use is definitely more transparent and controlled, as it takes place within the legally defined budget process.

It is determined that ensuring the financial security of UTC is based on the observance of financial discipline by the executive bodies of communities, as well as on the basis of careful planning and control of revenues and expenditures to the UTC budget. It was investigated that the most important element of financial security of territorial communities is investment, as it is potentially able to provide the largest share of financial revenues for the needs of sustainable community development.

Keywords: UTC, financial security, investments, budget decentralization, finances of territorial communities. 
Постановка проблеми. Специфіка сучасного етапу реформи децентралізації, котра відбувається в Україні, полягає у переході об'єднаних територіальних громад до повноцінного функціонування в рамках нового бюджетного процесу та реорганізованих фінансових повноважень територіальних громад, як органів місцевого самоврядування. При цьому необхідно зазначити, що після стартового періоду, котрий для ОТГ супроводжувався дотаційними трансфертами, спрямованими на забезпечення високих стартових позицій у сфері реалізації проектів регіонального розвитку, в даний час ОТГ змушені перейти на самостійне регулювання фінансових потоків, що надходять до їхніх бюджетів. В таких умовах особливої актуальності набуває забезпечення належного контролю за надходженням та використанням коштів територіальних громад, які спрямовуються на забезпечення їх потреб, а також повинні використовуватися на цілі, котрі визначають сталий розвиток відповідних регіонів. Відповідно, формується система фінансової безпеки ОТГ, яка має на меті дотримання виконання усіх законодавчих норм щодо забезпечення прозорості та законності використання коштів об'єднаних територіальних громад.

Крім того, важливим аспектом фінансової безпеки ОТГ виступає забезпечення належної взаємодії з потенційними інвесторами в рамках державно-приватного партнерства. Особливий механізм, котрий імплементовано в систему функціонування об'єднаних територіальних громад, передбачає залучення коштів приватних інвесторів в забезпечення сталого розвитку територій, шляхом реалізації проектів, пріоритетних для забезпечення належного соціально-економічного розвитку громади. Таким чином, дослідження особливостей взаємодії ОТГ та зовнішніх інвесторів, набуває особливої актуальності в аспекті необхідності забезпечення їх сталого розвитку.

Аналіз останніх досліджень і публікацій. Вивченню специфічних особливостей забезпечення фінансової безпеки регіонів та об'єднаних територіальних громад присвячені роботи багатьох авторитетних дослідників та науковців. Зокрема, вагомий внесок у дослідження даного питання здійснили такі вчені, як Н. Бак [1], С. В. Бурлуцький та С. В. Бурлуцька [4], М. І. Виклюк [5], О. С. Власюк [6], С. С. Гасанов [7] та багато інших. Разом з тим, необхідно також розглянути дослідження, присвячені забезпеченню фінансової безпеки регіонів та територіальних громад в аспекті бюджетної децентралізації, вагомий внесок в які здійснено такими відомими вченими та практиками, як С. Я. Бугіль [2], Т. І. Єфименко [8, 9], В. Д. Залізко [10], О. Кириленко та О. В. Стащук [11], І. Микитюк [12], О. В. Тимошенко [13] та багатьма іншими.

Таким чином, сучасна економічна думка має у своєму розпорядженні достатню кількість напрацювань у сфері забезпечення фінансової безпеки регіону та об'єднаних територіальних громад. Однак завершення основного етапу реформи децентралізації в Україні, пов'язані, в тому числі, і 3 бюджетною децентралізацією, призвели трансформації системи фінансових відносин в об'єднаних територіальних громадах, що потребує більш детального дослідження специфіки забезпечення фінансової безпеки ОТГ.

Виділення невирішених раніше частин загальної проблеми. Як свідчить практика досліджень особливостей забезпечення фінансової безпеки об'єднаних територіальних громад в Україні, а також 3 врахуванням досвіду регулювання бюджетних та фінансових відносин в регіональних органах управління зарубіжних країн, існують усталені погляди щодо практики забезпечення цієї безпеки. Однак, в дійсності фінансова безпека в даний час не розглядається як окрема система, а включає в себе комплекс напрямків, котрі включають інвестиційну, податкову, бюджетну та іншу безпеку і які усі разом становлять собою структуру фінансової безпеки ОТГ. Тому, на нашу думку, існує об'єктивна потреба пошуку нових підходів щодо реальної оцінки фінансової безпеки об'єднаних територіальних громад в аспекті забезпечення належного іiі рівня 3 метою досягнення цілей сталого розвитку відповідної громади та ефективної реалізації іiї соціальноекономічної політики.

Виклад основного матеріалу. Традиційні підходи до забезпечення фінансової безпеки регіонів або об'єднаних територіальних громад зосереджують свою увагу на тих аспектах їх діяльності, котрі безпосередньо пов'язані із забезпеченням належного обсягу надходжень до бюджетів ОТГ згідно планових показників, а також - на необхідності ефективного контролю за видатками місцевих бюджетів. Таким чином, оцінка фінансової безпеки зосереджується виключно на бюджеті територіальної громади і контролі за дисципліною виконання його надходжень і видаткової частини. 
Однак, такий підхід $€$ характерним для колишньої системи вертикального централізованого бюджетного підпорядкування, коли фінансова дисципліна визначала усі аспекти взаємовідносин в процесі формування і розподілу бюджетних коштів між центральними органами влади та органами місцевого самоврядування і не $є$ цілком адекватним сучасним реаліям.

В даний час більш актуальним є підхід, коли фінансова безпека грунтується на більш широкому розумінні системи бюджетних та фінансових взаємовідносин об'єднаної територіальної громади ,котра включає в себе і домогосподарства, і суб'єкти господарювання, котрі функціонують в межах ОТГ. При цьому мова ведеться не про рівень окремої громади, а про фінансову безпеку території, на якій ця ОТГ функціонує, що потребує визначення зв'язків взаємодії у сфері фінансової безпеки (рис. 1).

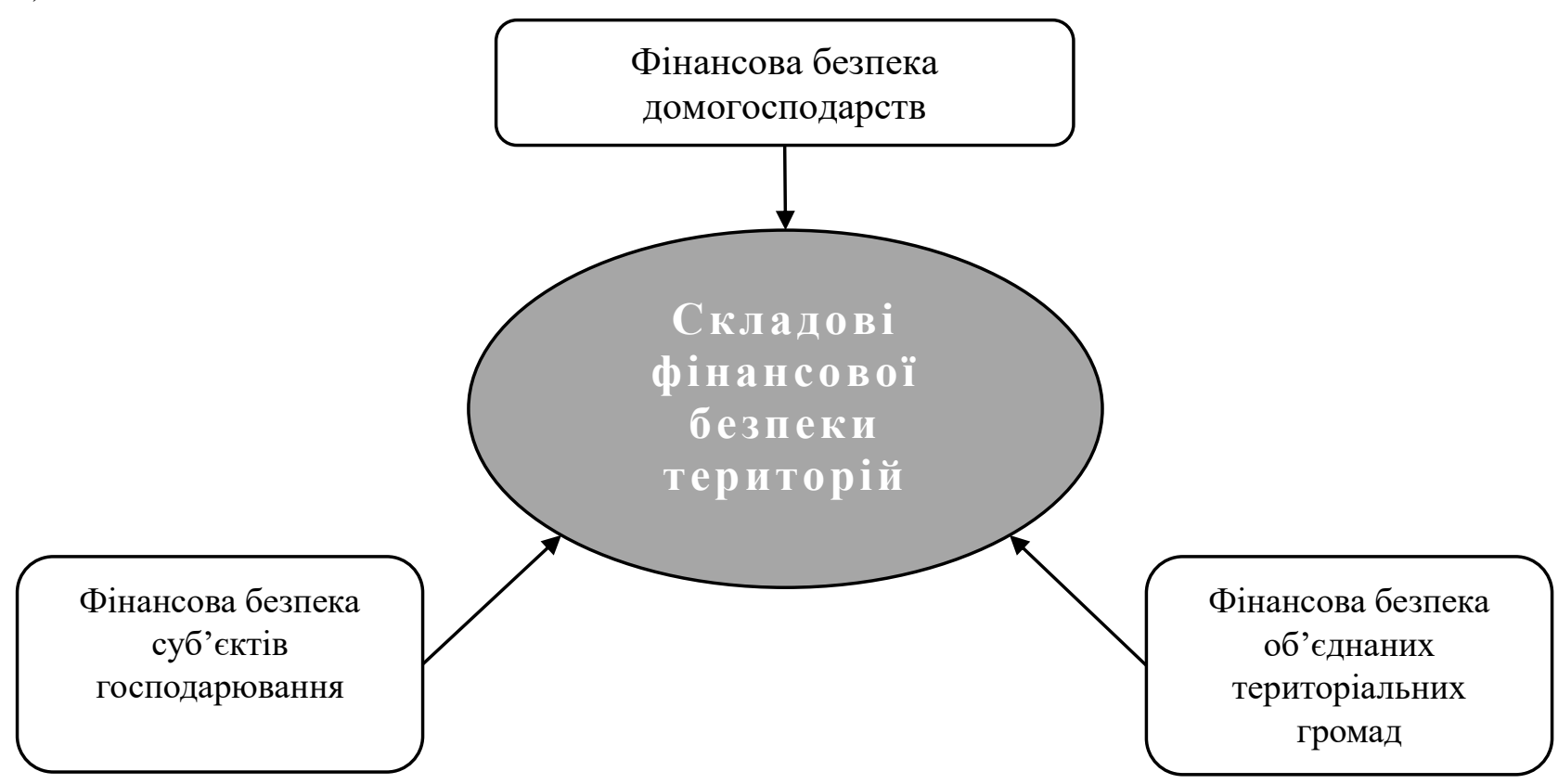

Рис. 1. Складові елементи фінансової безпеки територій

Дожерело: [1]

Таким чином, можна стверджувати, що фінансова безпека територіальних громад являє собою складну структуру різноманітних елементів, котрі являють собою окремі напрями безпеки у різних сферах фінансової діяльності. Відповідно, характеризуючи дану структуру, можна визначити найбільш типові елементи, що стосуються фінансової безпеки об'єднаних територіальних громад, а саме:

1. Банківська безпека. Стосується системи банківського та фінансового обслуговування населення, що проживає на території громади. При цьому враховується не лише доступність для населення банківського обслуговування, але й надійність самих банківських установ, що діють на території громади. Разом з тим, в умовах формування цифрової економіки і широкого поширення Інтернет-банкінгу, питання забезпечення банківської безпеки відходять на другий план, оскільки ринок в даному аспекті залишається поділеним між крупними банками, які є більш надійними у порівнянні з малими регіональними банківськими установами.

2. Безпека фінансових послуг небанківського характеру - залежить від рівня розвитку та доступу до таких послуг для мешканців територіальної громади. Зважаючи на специфіку такого бізнесу, ризики такого характеру властиві лише громадам великих міст. Але, знову ж таки, виходячи з значного поширення онлайн-доступу до фінансових послуг за допомогою Інтернету, забезпечення такої безпеки необхідно досягати шляхом загального підвищення рівня фінансової грамотності населення територіальних громад.

3. Боргова безпека - стосується ризиків повернення позичок територіальною громадою у випадку залучення позикових коштів на банківському ринку або шляхом випуску боргових 
зобов'язань у формі цінних паперів. Рівень боргової безпеки визначається співвідношенням загального обсягу залучених ОТГ коштів до обсягу надходжень до ії бюджету у плановому періоді, які можуть бути використані для погашення взятих зобов'язань. Значною мірою рівень боргової безпеки залежить від якості фінансового планування територіальної громади та контролю за використанням коштів їі бюджету.

4. Валютна безпека - може виникати у випадку залучення ОТГ коштів іноземних інвесторів для реалізації проектів розвитку територіальної громади або за умови залучення валютних позик на фінансовому ринку. Даний вид безпеки не надто характерний для українських ОТГ. Проте громади $\epsilon$ найменш захищеними від ризиків такого плану, оскільки не мають у своєму розпорядженні жодних інструментів регулювання даних фінансових процесів.

5. Бюджетна безпека - визначається загальним рівнем фінансової спроможності об'єднаної територіальної громади, що включає в себе обсяги надходжень до бюджету громади та диференціацію ї джерел, а також значною мірою залежить від обсягу видатків, які необхідні для підтримання діяльності громади, включаючи усі проекти сталого розвитку, що реалізуються на ії території, а також соціальну інфраструктуру. Бюджетна безпека також значною мірою залежить від якості контролю за виконанням бюджетів територіальних громад і базується на традиційних підходах дотримання фінансової дисципліни, котрі розроблені для регіональних бюджетів.

6. Грошово-кредитна безпека - полягає в забезпеченні доступу мешканців територіальних громад та суб'єктів господарювання, що функціонують на іiі території, до дешевих кредитних ресурсів для забезпечення власного добробуту або розширення бізнесу. В даному аспекті територіальні громади можуть виконувати роль посередника між банківськими установами i суб'єктами ОТГ для забезпечення вказаних потреб.

7. Податкова безпека - полягає, головним чином, забезпеченні фінансової дисципліни з боку платників податків, що функціонують на території територіальної громади. При цьому ОТГ повинні забезпечувати якісну співпрацю з господарюючими суб'єктами для сприяння їх ефективній діяльності, що матиме наслідком наявність достатніх фінансових ресурсів для виконання ними податкових зобов'язань перед бюджетом територіальної громади. Як показує практика, рівень податкової безпеки є низьким для громад, які залежать від одного або кількох системоутворюючих підприємств. А також управління податковою безпекою у великих громадах $\epsilon$ на порядок складнішим, ніж в невеликих сільських ОТГ.

Таким чином, загалом можна стверджувати, що на основі оцінки головних структурних елементів фінансової безпеки об'єднаних територіальних громад виникає можливість визначити головну характеристику фінансової безпеки ОТГ, як іiі здатність, дотримуватися стійкості щодо ризиків, які визначаються елементами фінансової безпеки, а також виконувати свої фінансові зобов'язання згідно визначених бюджетом громади та планами іiі розвитку потреб. Усе це у кінцевому підсумку матиме наслідком забезпечення зростання можливостей щодо досягнення цілей сталого розвитку територіальної громади у плановому періоді, оскільки стабільність фінансових потоків ОТГ визначатиме й стабільність фінансування усіх проектів соціально-економічного розвитку, котрі реалізуються на іiі території. При цьому саме фінансова безпека і $є$ основою для прийняття інвесторами рішень щодо участі в таких проектах територіальних громад.

Як свідчить практика, після проходження процесу бюджетної децентралізації в Україні, саме бюджетна безпека є визначальним елементом фінансової безпеки об'єднаних територіальних громад. Відповідно, оцінка фінансової безпеки також головним чином базується на оцінці рівня бюджетної безпеки громади. В практичній площині конкретні показники, що характеризують бюджетну безпеку, визначаються Бюджетним кодексом України і є цілком застосовуваними для бюджетів реформованих ОТГ (табл. 1).

Однак на практиці, фінансова безпека територіальних громад також залежить не лише від дотримання нормативів виконання й наповнення їх бюджетів, але й визначається впливом зовнішніх та внутрішніх факторів, котрі формують специфіку середовища, в якому функціонує ОТГ. 
Індикатори фінансової стійкості бюджетів ОТГ

\begin{tabular}{|c|c|}
\hline Індикатори & Значення показника \\
\hline $\begin{array}{l}\text { Оборотний } \\
\text { бюджетних коштів }\end{array}$ & $\begin{array}{l}\text { Не більше } 2 \% \text { планових видатків загального фонду бюджету. На } \\
\text { кінець бюджетного періоду оборотний залишок бюджетних коштів має } \\
\text { бути збережений у встановленому розмірі }\end{array}$ \\
\hline $\begin{array}{lr}\text { Мiсцеві } & \text { гарантії для } \\
\text { забезпечення } & \text { виконання } \\
\text { боргових } & \text { зобов'язань } \\
\text { суб'єктів господарювання }\end{array}$ & $\begin{array}{l}\text { Надаються на умовах платності, строковості, а також забезпечення } \\
\text { виконання зобов'язань у спосіб, передбачений законом }\end{array}$ \\
\hline $\begin{array}{l}\text { Загальний обсяг місцевого } \\
\text { боргу }\end{array}$ & $\begin{array}{l}\text { He } \quad \text { може перевищувати } 200 \% \text { середньорічного } \\
\text { прогнозного обсягу надходжень бюджету розвитку }\end{array}$ \\
\hline Резервний фонд бюджету & $\begin{array}{l}\text { Не може перевищувати 1\% обсягу видатків загального фонду } \\
\text { бюджету. Порядок використання коштів визначається Кабінетом } \\
\text { Міністрів України }\end{array}$ \\
\hline $\begin{array}{l}\text { Видатки місцевого бюджету } \\
\text { на обслуговування місцевого } \\
\text { боргу }\end{array}$ & $\begin{array}{l}\text { Не можуть перевищувати } 10 \% \text { видатків загального фонду місцевого } \\
\text { бюджету }\end{array}$ \\
\hline
\end{tabular}

Дюерело: [3]

Відповідно, говорячи про бюджетну безпеку територіальних громад, необхідно враховувати вплив таких факторів і для забезпечення високої ефективності фінансової діяльності громади загалом, необхідно формувати стратегію іiї розвитку, яка і повинна базуватися на засадах фінансової безпеки.

Ключовими елементами такої стратегії повинні бути безпосередньо бюджетна стратегія ОТГ, а також формування дієвої системи контролю за виконанням бюджетних заходів територіальної громади та визначення інструментів оперативного втручання у випадках, коли планові показників стратегії розвитку ОТГ відхиляються від фактичних в процесі виконання їх бюджету. Для цього необхідно визначити конкретні принципи реалізації моніторингу виконання бюджету об'єднаної територіальної громади, а також узгодити саму стратегію з конкретними цілями сталого розвитку громади і проектами, які задля реалізації цих цілей реалізуються в плановому періоді.

Висновки та пропозиції. Отже, можна стверджувати, що досягнення належного рівня фінансової безпеки об'єднаних територіальних громад неможливе без визначення ключових структурних елементів цієї безпеки, які є найбільш важливими для кожної окремої громади. При цьому на основі визначення таких пріоритетів необхідно сформувати стратегію фінансової безпеки ОТГ, узгоджену з їі бюджетними можливостями та плановими показниками щодо цілей сталого розвитку громади. При цьому практична реалізація будь-яких проектів по соціально-економічному розвитку територіальної громади повинна передбачати необхідність оцінки потенційних ризиків від впровадження таких проектів, а також потребує узгодження із стратегією розвитку ОТГ саме в аспекті необхідності дотримання фінансової безпеки в процесі реалізації проекту.

\section{Джерела та література}

1. Бак Н. Фінансова безпека територіальних громад в Україні: сутність, структурні складові, загрози. Світ фінансів. 2019. № 1(58). С. 98-110.

2. Бугіль С. Я. Фінансова стійкість та безпека місцевих бюджетів в умовах обмеженості фінансових ресурсів. Соціально-економічні проблеми сучасного періоду Украӥни. 2016. №1. С. 55-60.

3. Бюджетний Кодекс України від 20 вересня 2015 p. №2456-VI. URL: https://zakon.rada.gov.ua/laws/show/2456-17/ed20150920\#Text (дата звернення: 01.08.2021).

4. Бурлуцький С. В., Бурлуцька С. В. Економічна та фінансова безпека регіонів в умовах децентралізації. Вісник Східноукраӥнського наџіонального університету імені Володимира Даля. 2015. № 6. С. 16-21.

5. Виклюк М. І. Структура фінансової безпеки регіону та характеристика ії складових. Ефективна економіка. 2012. №10.

6. Власюк О. С. Актуальні проблеми фінансової безпеки України в умовах посткризової трансформації. 
Київ : НІСД. 2014. 432 с.

7. Гасанов С. С. Фіскальні правила і фіскальна відповідальність: контекст економічної безпеки. Фінанси Украӥни. 2018. № 3. С. 7-23. $7-30$.

8. Єфименко Т. І. Монетарні інструменти економічної безпеки держави. Фінанси Украӥни. 2018. № 1. С.

9. Єфименко Т. І. Фіскальна та монетарна безпека національної економіки. Київ : ДННУ «Акад. фін. управління». 2016. 447 с.

10. Залізко В.Д. Економічна безпека сільських територій: сутність поняття, структура, функції. Науковий вісник Львівського державного університету внутрішніх справ. - “Серія економічна”. 2013. № 1. С. 49-56.

11. Кириленко О., Стащук О. Оцінювання макроекономічних чинників формування фінансової безпеки України. Світ фінансів. 2017. Вип. 2. С. 7-16.

12. Микитюк І. Фінансова стійкість та безпека місцевого бюджету. Вісник КНТЕУ. 2013. №1. С. 86-97.

13. Тимошенко О. В. Фінансова децентралізація як напрям посилення економічної безпеки регіонів. Економіка і регіон. 2016. № 1. С. 82-89.

\section{References}

1. Bak, N. (2019). Finansova bezpeka terytorialnykh gromad v Ukraini: sutnist, strukturni skladovi, zagrozy [Financial security of territorial communities in Ukraine: essence, structural components, threats]. Svit finansiv World of Finance. Vol. 1(58), 98-110 [in Ukrainian].

2. Bugil, S. Ia. (2016). Finansova stiikist ta bezpeka mistsevykh budzhetiv v umovakh obmezhenosti finansovykh resursiv [Financial stability and security of local budgets in conditions of limited financial resources]. Sotsialno-ekonomichni problem suchasnogo periode Ukrainy - Socio-economic problems of the modern period of Ukraine. Vol. 1, 55-60 [in Ukrainian].

3. Budget Code of Ukraine (20 September 2015) №2456-VI. Retrieved from: https://zakon.rada.gov.ua/laws/show/2456-17/ed20150920\#Text (accessed on: 01 Aug. 2021) [in Ukrainian].

4. Burlutskyi, S.V., Burlutska, S.V. (2015). Ekonomichna ta finansova bezpeka regioniv v umovakh detsentralizatsii [Economic and financial security of regions in the decentralization conditions]. Visnyk Skhidnoukrainskoho natsionalnoho universytetu imeni Volodymyra Dalia - Bulletin of the Volodymyr Dahl East Ukrainian National University. Vol. 6, 16-21 [in Ukrainian].

5. Vykliuk, M. (2012). Struktura finansovoi bezpeky rehionu ta kharakterystyka yii skladovykh [Structure and financial security area characteristics of its components]. Efektyvna ekonomika - Effective economy. Vol. 10 [in Ukrainian].

6. Vlasiuk, O.S. (2014). Aktualni problemy finansovoi bezpeky Ukrainy v umovakh postkryzovoi transformatsii [Actual problems of financial security of Ukraine in the conditions of post-crisis transformation]. Kyiv: NISD [in Ukrainian].

7. Gasanov, S.S. (2018). Fiskalni pravyla i fiskalna vidpovidalnist: kontekst ekonomichnoi bezpeky [Fiscal rules and fiscal responsibility: economic security context]. Finansy Ukrainy - Finance of Ukraine. Vol. 3, 7-23 [in Ukrainian].

8. Yefymenko, T.I. (2018). Monetarni instrumenty economichnoi bezpeky derzhavy [Monetary tools of the state economic security]. Finansy Ukrainy - Finance of Ukraine. Vol. 1, 7-30 [in Ukrainian].

9. Yefymenko, T.I. (2016). Fiskalna ta monetarna bezpeka natsionalnoi ekonomiky [Fiscal and monetary security of national economy]. - Kyiv [in Ukrainian].

10. Zalizko, V.D. (2013). Ekonomichna bezpeka silskykh terytorii: sutnist poniatia, struktura, funktsii [Economic security of rural arias: essence of the concept, structure, functions]. Naukovyi visnyk Lvivskoho derzhavnoho universytetu vnutrishnikh sprav. Seriia "Ekonomichna" - Scientific Bulletin of Lviv State University of Internal Affairs. Vol. 1, 49-56 [in Ukrainian].

11. Kyrylenko, O., Stashchuk, O. (2017). Otsinyuvania makroekonomichnykh chynykiv formuvania finansovoi bezpeky Ukrainy [Evaluation of macroeconomic factors formation of financial security of Ukraine]. Svit financiv World of Finance. Vol. 2, 7-16 [in Ukrainian].

12. Mykutiuk I. (2013). Finansova stiykist ta bezpeka mistsevogo byudzhetu [Financial stability and safety of the local budget]. Visnyk KNTEU - Bulletin of KNTEU. Vol. 1, 86-97. [in Ukrainian].

13. Tymoshenko, O.V. (2016). Finansova detsentralizatsiia yak napriam posylenia ekonomichnoi bezpeky rehioniv [Financial decentralization as the direction of strengthening of the region economic security]. Ekonomika $\mathrm{i}$ rehion - Economics and region. Vol. 1, 82-89 [in Ukrainian].

Стаття надійшла до редакції 20.08.2021 р. 